\title{
Influence of spatial differentiation in impact assessment for LCA-based decision support: Implementation of biochar technology in Indonesia
}

\author{
Owsianiak, Mikoaj; Cornelissen, Gerard; Hale, Sarah E.; Lindhjem, Henrik; Sparrevik, Magnus
}

Published in:

Journal of Cleaner Production

Link to article, DOI:

10.1016/j.jclepro.2018.07.256

Publication date:

2018

Document Version

Peer reviewed version

Link back to DTU Orbit

Citation (APA):

Owsianiak, M., Cornelissen, G., Hale, S. E., Lindhjem, H., \& Sparrevik, M. (2018). Influence of spatial differentiation in impact assessment for LCA-based decision support: Implementation of biochar technology in Indonesia. Journal of Cleaner Production, 200, 259-268. https://doi.org/10.1016/j.jclepro.2018.07.256

\section{General rights}

Copyright and moral rights for the publications made accessible in the public portal are retained by the authors and/or other copyright owners and it is a condition of accessing publications that users recognise and abide by the legal requirements associated with these rights.

- Users may download and print one copy of any publication from the public portal for the purpose of private study or research.

- You may not further distribute the material or use it for any profit-making activity or commercial gain

- You may freely distribute the URL identifying the publication in the public portal 
1 Owsianiak, M., Cornelissen, G., Hale, S. E., Lindhjem, H., \& Sparrevik, M. (2018). Influence of spatial 2 differentiation in impact assessment for LCA-based decision support: Implementation of biochar technology 3 in Indonesia. Journal of Cleaner Production, 200, 259-268. DOI: 10.1016/j.jclepro.2018.07.256 


\section{Influence of spatial differentiation in impact assessment for LCA-based decision}

\section{5 support: implementation of biochar technology in Indonesia}

6 Mikołaj Owsianiak $^{\mathrm{a}^{*}}$, Gerard Cornelissen ${ }^{\mathrm{b}, \mathrm{c}}$, Sarah E. Hale $^{\mathrm{b}}$, Henrik Lindhjem ${ }^{\mathrm{d}, \mathrm{e}}$ and Magnus

$7 \quad$ Sparrevik $^{\mathrm{f}}$

8 a Division for Quantitative Sustainability Assessment, Department of Management Engineering,

9 Technical University of Denmark, Kongens Lyngby, Denmark

$10{ }^{\mathrm{b}}$ Department of Environmental Engineering, Norwegian Geotechnical Institute (NGI), Oslo,

11 Norway

$12{ }^{\mathrm{c}}$ Faculty of Environmental Sciences and Natural Resources (MINA), Norwegian University of Life

13 Sciences (NMBU), Ås, Norway

$14{ }^{\mathrm{d}}$ Menon Centre for Environmental and Resource Economics, Oslo, Norway

$15{ }^{\mathrm{e}}$ Norwegian Institute for Nature Research (NINA), Oslo, Norway

$16{ }^{\mathrm{f}}$ Department of Industrial Economics and Technology Management, Norwegian University of

17 Technology, Trondheim, Norway

18 * corresponding author: miow@dtu.dk; tlf. +45 4525 4805; fax. +45 4593 3435; Bygningstorvet

19 115-116B, DK-2800 Kgs. Lyngby, Denmark 
- Spatial differentiation was found important for total damage to human health

- Spatial differentiation was less relevant for total damage to ecosystems

- Tradeoffs between impact categories influenced total scores

- Geographical variations in inventory flows influenced comparisons

- Spatial differentiation did not necessarily lead to better decisions 


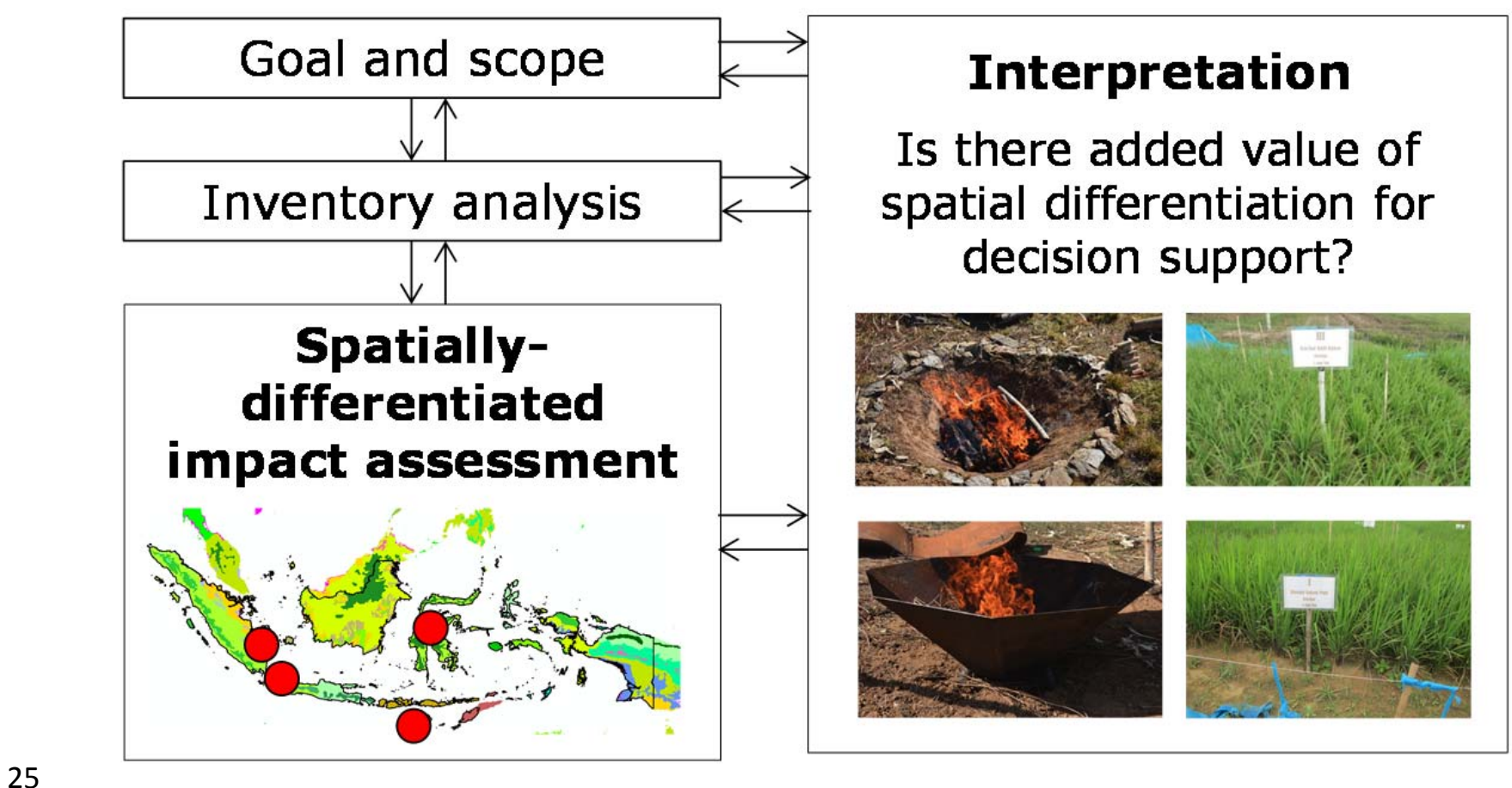

26 Graphical abstract 


\section{Abstract}

Spatial differentiation in evaluation of environmental impacts in life cycle assessment (LCA) may give more accurate and realistic results, especially in cases where impacts occur at a local or regional scale and where sensitivity of receiving ecosystems differs from generic conditions. However, from a decision maker's perspective it is of interest to investigate whether the use of spatially differentiated impact assessment methods in addition leads to better decisions. Biochar production and agricultural utilization in Indonesia is an example of a micro-level decision-support case where spatial differentiation could be relevant.

To study the influence of spatial differentiation on implementation of biochar as a waste management strategy and the choice of best performing biochar production techniques, agricultural utilization systems and geographic locations, comparisons were made between four communities living on different Indonesian islands, three biochar production techniques and two types of fertilizer.

Results showed that the differences in impact scores between generic and spatially differentiated impact scores were an order of magnitude different for some of the considered impact categories. These differences influenced the identification of which system performed best when considering total damage to human health, which was mainly due to differences in accounting for impacts arising from water use. By contrast, trade-offs between impact categories combined with relatively small contribution of some spatially differentiated impacts rendered spatial differentiation less relevant with regard to total damage to ecosystems. Total impact scores were influenced to a greater extent by variations in inventories determining environmental burden and benefits, than by differences between generic and spatially differentiated characterization factors. Hence, irrespective of the scenario and type of damage considered, both generic and spatially differentiated assessments 
showed that implementing biochar technology in Indonesia is expected to bring environmental benefits.

It was shown that spatial differentiation in impact assessment did not necessary lead to better decisions in this case study. This may suggest that depending on the goal of the LCA, practitioners should consider potential benefits of implementing spatially differentiated life cycle impact assessment methods as opposed to potential benefits from collecting site-specific inventories.

\section{Keywords}

decision-making, decision-support, LCA, LCIA, regionalization, spatialization

\section{Introduction}

Life cycle impact assessment (LCIA) the part of life cycle assessment (LCA) in which the life cycle inventory of a system's material flows is translated into their potential contributions to the environmental impacts. LCIA supports the interpretation phase of the LCA, where questions posed in the goal definitions are answered (Hauschild and Huijbregts, 2015). Spatially differentiated life cycle impact assessment (LCIA) methods enable execution or regionalized life cycle assessment (LCA) studies as they take into consideration local conditions and sensitivities of receiving ecosystems. In contrast to generic methods, which should be valid on a global scale (at the expense of higher spatial uncertainty), spatially-differentiated LCIA methods are more accurate as they operate at either regional or local scales, corresponding to site-dependent and site-specific assessments, respectively (Potting and Hauschild, 2006). In this paper, we studied the influence of the choice of spatially differentiated LCIA methods on the interpretation phase of an LCA. The development of spatially differentiated LCIA methods has intensified in the past few years (Patouillard et al., 2018; Rosenbaum et al., 2018; Verones et al., 2017). A review of 
characterization models included in spatially differentiated LCIA methods, like IMPACT World+ (Bulle et al., 2012) or LC-Impact (Verones et al., 2016), is given in Rosenbaum (2018).

Examinations of these models shows, that depending on the impact category, geographic variability in characterization factors (CF) can be higher than differences in characterization factors between substances covered by the method. Applications of such methods in LCA studies results in more accurate and realistic evaluations of environmental impacts, as was demonstrated for the few regionalized LCA studies published to date (Anton et al., 2014; Heidari et al., 2017; Henderson et al., 2017a; Mutel et al., 2011).

LCA is a decision support tool. Two (out of three) commonly used archetype goal situations (namely, situation A for micro-level decision support and situation B for meso/macro-level decision support) involve a decision context (Bjørn et al., 2018a; European Commission, 2010). It is therefore of interest to investigate whether the use of spatially differentiated LCIA methods leads to better decisions, in addition to more accurate and realistic LCIA results. Our research question is therefore: does spatial differentiation in life cycle impact assessment lead to better decisions? The answer to this research question is not obvious. Even large differences in impact scores for individual impact categories might become less influential for decision support. This could be due to potential trade-offs between impact categories (Heidari et al., 2017), due to a larger influence of spatial variability in inventory flows compared to spatial differences in characterization factors (Henderson et al., 2017b), or due to a smaller contribution of spatially-differentiated impact categories to total damage. The influence of spatial differentiation in impact assessment on LCAbased decision support has not previously been investigated. Spatial differentiation may be particularly important for application of biochar systems in tropical rural areas like Indonesia, where conditions with regard to biodiversity or water availability can vary significantly from generic characterization factors used in traditional LCA (Boulay et al., 
2011; Chaudhary et al., 2015). Biochar is typically used as soil conditioner, increasing crop productivity while contributing to climate change mitigation through carbon sequestration and storage (Lehmann, 2007; Woolf et al., 2010). Biochar is produced from biomass residues, and in developing and middle-income countries often small-scale, low-cost pyrolysis technologies traditionally based on earth-mound kilns are used (Nsamba et al., 2015). Alternatively, more innovative and cleaner flame curtain (“Kon-Tiki”) kilns or retort kilns made out of bricks and steel, can be used (Cornelissen et al., 2016; Sparrevik et al., 2015). Experimental studies have shown that biochar production leads to emission of toxic organic compounds and greenhouse gases (Cornelissen et al., 2016; Sparrevik et al., 2015). Environmental impacts from biochar systems have previously been assessed using LCA (e.g. Galgani and Delft, 2012; Gwenzi et al., 2015; Sparrevik et al., 2014). However, the relative immaturity of spatially differentiated LCIA approaches and their limited implementation into LCA modelling software, have restricted the use of spatially differentiated methods in these studies.

The objective of this study was therefore to assess implications of spatial differentiation in LCIA on decision support related to implementation of a biochar systems in Indonesia. For this purpose, generic and spatially differentiated impact scores were calculated and compared using a suite of relatively recent LCIA methods, which offer spatially differentiated characterization factors at the damage level. Firstly, the influence on an absolute scale, i.e. whether the conversion of biomass residues to biochar and its subsequent use in agriculture provides has a net positive effect compared to the current situation (no treatment of biomass residues), was investigated. Secondly, when selecting management strategies, decision makers must know in which geographic locations biochar systems are expected to perform optimally, and furthermore which biochar production technique and biochar application conditions (inorganic vs. organic fertilizer based agriculture) perform best from an environmental point of view. Thus, the effect of spatial differentiation on the 
relative importance for ranking of subsystems and technologies was assessed. Finally, decision makers may be interested in identifying potential improvements for biochar systems, and a process contribution analysis, i.e. identifying the processes with the largest environmental burden, can be used for this purpose. Thus, the impact of spatial influence on process contribution was examined.

\section{Methods}

\subsection{Goal and scope}

The goals of the LCA were three fold: The first goal was to assess and compare life cycle impacts of biochar systems in Indonesia in order to support decision making related to the implementation of biochar as a waste management strategy in four Indonesian island communities. The second goal was to identify the best biochar production technique and agriculture practice in these communities. The third goal was to identify improvement potentials for the biochar systems. The results of this LCA are used to discuss the effect on spatial differentiation for LCA-based decision support in the Indonesian context.

The LCA was carried out following the requirements of the ISO standards and the guidelines of the International Reference Life Cycle Data System (ILCD) handbook (European Commission, 2010; European Committee for Standardization, 2006a, 2006b) According to the ILCD guidelines, the current study is a micro-level decision support (type-A) situation, and the assessment carried out applies an attributional approach in accordance with the recommendations of the ILCD guidelines for this decision support type. A system expansion (through crediting) using average processes in this attributional approach, consistent with both ILCD and the ISO hierarchy for solving multifunctionality, was therefore applied (Bjørn et al., 2018b).

\subsubsection{Functional unit and system boundaries}


The primary function of the biochar systems in this context is to utilize biomass waste to produce biochar and use of this biochar as a soil conditioner. Thus, the functional unit was defined as the "treatment of $1 \mathrm{~kg}$ of biogenic carbon from biomass residues in rural areas in Indonesia". This definition allows for a fair comparison between residues treated using different techniques. A secondary function of biochar when used as soil conditioner is its ability to support crop growth. In this case, the benefits from increasing yields are modelled as avoided production of crops (mainly fertilizer use). In addition, system boundaries included the complete underlying biochar production life cycle, including the construction of the biochar kilns and production of biochar from biowaste (Fig. 1). Avoided impacts from current waste management system are also relevant to considered, but in this case there is no treatment of biomass residues, which are allowed to decompose in aerobic conditions. Thus, following Sparrevik et al., (2014) no net emissions of carbon dioxide and no emission of methane during decomposition of biomass residues were assumed.

\section{Fig. 1.}

\subsubsection{Biochar systems investigated}

The influence of spatial differentiation was studied by using site specific inventory data from four distinct geographic locations of Indonesia (Ngata Toro on the island of Sulawesi, Napu on Sumba, Lampung on Sumatra, and Lamongan on Java) (see SI, Section S1 for details). On the basis of previous work in Nepal and Zambia, the most promising method for the production of biochar in the four villages was considered to be the flame curtain technique (Table 1, scenarios 1-4) (Cornelissen et al., 2016; Schmidt et al., 2014). This novel production technology was compared to biochar systems based on other available alternative production technologies, such as retort kilns (the Adam retort) (Adam, 2009) and simple non-retort earth-mound kilns (Table 1, scenarios 5-12). Inorganic fertilizers (N, P, K, and urea) are used in all villages, except for Napu where compost is used. Thus, comparisons were made with compost as the sole source of nutrient input in Ngata 
Table 1. Overview of the compared biochar systems.

\begin{tabular}{|c|c|c|c|c|}
\hline \# Scenario & $\begin{array}{l}\text { Sensitivity } \\
\text { parameter }\end{array}$ & $\begin{array}{l}\text { Geographic location } \\
\text { (production and use) }^{\mathrm{a}}\end{array}$ & $\begin{array}{l}\text { Biochar production } \\
\text { technique }^{\mathrm{b}}\end{array}$ & $\begin{array}{l}\text { Fertilizer type and } \\
\text { amount }^{\mathrm{c}}\end{array}$ \\
\hline 1 & Baseline & NT & $\begin{array}{l}\text { "Kon-Tiki" flame } \\
\text { curtain kiln }\end{array}$ & $\begin{array}{l}\text { NPK and urea } \\
\text { fertilizers }\end{array}$ \\
\hline $3-4$ & $\begin{array}{l}\text { Geographic } \\
\text { location of biochar } \\
\text { production and use }\end{array}$ & $\mathrm{N}, \mathrm{LS}, \mathrm{LJ}$ & $\begin{array}{l}\text { "Kon-Tiki" flame } \\
\text { curtain kiln (all } \\
\text { locations) }\end{array}$ & $\begin{array}{l}\text { NPK and urea } \\
\text { fertilizers (NT, LS, } \\
\text { LJ); compost (N) }\end{array}$ \\
\hline $5-12$ & $\begin{array}{l}\text { Biochar production } \\
\text { technique }\end{array}$ & $\mathrm{NT}, \mathrm{N}, \mathrm{LS}, \mathrm{LJ}$ & $\begin{array}{l}\text { retort kiln (all } \\
\text { locations); earth } \\
\text { mound kiln (all } \\
\text { locations) }\end{array}$ & $\begin{array}{l}\text { NPK and urea } \\
\text { fertilizers (NT, LS, } \\
\text { LJ); compost (N) }\end{array}$ \\
\hline $13-24$ & $\begin{array}{l}\text { Fertilizer type and } \\
\text { amount }\end{array}$ & $\mathrm{NT}, \mathrm{N}, \mathrm{LS}, \mathrm{LJ}$ & $\begin{array}{l}\text { "Kon-Tiki" flame } \\
\text { curtain kiln, retort } \\
\text { kiln; earth mound kiln } \\
\text { (all locations) }\end{array}$ & $\begin{array}{l}\text { compost (NT, LS, } \\
\text { LJ); NPK and urea } \\
\text { fertilizers (N) }\end{array}$ \\
\hline
\end{tabular}

${ }^{a}$ NT: Ngata Toro; N: Napu; LS; Lampung, Sumatra; LJ: Lamongan, Java

${ }^{\mathrm{b}}$ retort kiln made from bricks and steel (Adam retort) and earth-mound kiln were alternatives to steel-made "Kon-Tiki” flame curtain kiln

\subsection{Life cycle inventory analysis}


Data for background processes, like construction of kilns or (avoided) production of inorganic

179

180 fertilizers are based on generic processes available in Ecoinvent, version 3.3 (Weidema et al., 2013). Ecoinvent is currently one of the most comprehensive databases of life cycle inventories.

Consideration of spatial differentiation in LCIA for these generic processes was not possible, as it is not known where emissions occur in the background system. Data for foreground processes in the biochar system, such as biochar production or soil application, should be represented as accurately as possible and were thus based on primary data measured in Indonesia and reported previously (Sparrevik et al., 2014), or collected specifically in surveys carried out for this work. Spatial differentiation was used in the LCIA in all relevant processes in the foreground system. All inventory data were site-specific representative field data aggregated from seven years of biochar research activities. This data, which included biochar properties, biochar application rate, irrigation and agricultural yields, varied between sites. Outdoor emissions resulting from the production of biochar, concentrations of $\mathrm{CO}_{2}, \mathrm{CO}, \mathrm{CH}_{4}, \mathrm{NMVOC}$, and $\mathrm{PM}_{10}$ and nitrous oxides, measured in Cornelissen et al., (2016) and Sparrevik et al., (2015) were used. Emissions of nitrate, phosphate, phosphorus and metals (co-contaminants) to soils, and emissions of GHG to air from organic and inorganic fertilizers were taken from generic Ecoinvent process for production of maize.

Differences in fertilizer amounts between the Ecoinvent process and amounts in these case studies were corrected for, assuming that composition of fertilizers with regard to metal content was the same. Site-specific data related to the mineralization kinetics of biochar in soil were not available for this study and as such were assumed to follow bi-exponential decay kinetics and average (geometric mean) kinetic parameters measured for six biochars representing a wide range of mineralization rate constants were therefore used (Zimmerman and Gao, 2013). Based on Woolf and Lehmann, (2012) a negative priming equal to $45 \%$ increase in soil organic carbon stock in the 
long-term (100 years) was used. Model parameters and underlying data are presented in the SI, Section S2. Unit processes for the foreground system are given in the SI, Section S3.

\subsection{Life cycle impact assessment}

To answer the research question (does spatial differentiation lead to better decisions?), spatially differentiated LCIA methods must be applied to all relevant categories of environmental impacts and must express impacts in common units. Hence, the following set of criteria was applied to choose LCIA methods: (i) a method must be published in peer-reviewed literature; (ii) it must offer modelling at damage level; (iii) it must allow a calculation of spatially-explicit impact score at sufficient resolution to be made (e.g. country- or Southeast-Asia level for regional impact categories like photochemical ozone formation, and island- or biome-level for local impact categories like land use); and (iv) it can be further adapted to specific geographic situation based on available details of the case study (e.g. adapting the particulate matter (PM) model to local exposure parameters). A comparison of impact assessment methods based on their environmental relevance or scientific robustness was not carried out here and no preference was given to one method over another for this study. Damage scores were computed allowing for weighting of impact categories contributing to total damage in two important areas of protection in LCIA: (i) human health, where impacts are expressed in disability adjusted life years, DALY; and (ii) ecosystem quality considering terrestrial, freshwater, and marine ecosystems, where impacts are expressed as loss of biodiversity (in speciesyears) (Hauschild and Huijbregts, 2015). The full list of LCIA methods with details of the spatial scales considered is given in Table 2. A detailed description of each method is presented in the SI,

\section{Section S5.}

Table 2. Generic and site-explicit LCIA methods for the impact categories considered in this study. 


\begin{tabular}{|c|c|c|c|c|}
\hline Impact category & $\begin{array}{l}\text { Area of } \\
\text { protection }\end{array}$ & $\begin{array}{l}\text { Impact score } \\
\text { unit }\end{array}$ & Geographical and temporal reference unit & Reference \\
\hline Climate change & Human health & DALY & Indonesia; 1-yr time steps & \multirow{3}{*}{$\begin{array}{l}\text { Levasseur et al., } \\
\text { 2010); ReCiPe2016 } \\
\text { (Huijbregts et al., } \\
\text { 2016); IPCC (2013); } \\
\text { Cherubini et al., } \\
\text { (2016) }\end{array}$} \\
\hline Climate change & $\begin{array}{l}\text { Ecosystems } \\
\text { (freshwater) }\end{array}$ & species $\times$ year & Indonesia; 1-yr time steps & \\
\hline Climate change & $\begin{array}{l}\text { Ecosystems } \\
\text { (terrestrial) }\end{array}$ & species $\times$ year & Indonesia; 1-yr time steps & \\
\hline $\begin{array}{l}\text { Ozone } \\
\text { depletion }\end{array}$ & Human health & DALY & Global & $\begin{array}{l}\text { ReCiPe2016 } \\
\text { (Huijbregts et al., } \\
\text { 2016) }\end{array}$ \\
\hline $\begin{array}{l}\text { Ionizing } \\
\text { radiation }\end{array}$ & Human health & DALY & Global & $\begin{array}{l}\text { ReCiPe2016 } \\
\text { (Huijbregts et al., } \\
2016 \text { ) }\end{array}$ \\
\hline $\begin{array}{l}\text { Particulate } \\
\text { matter } \\
\text { formation }\end{array}$ & Human health & DALY & $\begin{array}{l}\text { Outdoor rural: Southeast Asia } \\
\text { Indoor: air exchange rate for open building and } \\
\text { no attenuation, measured village-specific } \\
\text { exposure parameters (see Table S1) }\end{array}$ & (Fantke et al., 2017b) \\
\hline Land use & $\begin{array}{l}\text { Ecosystems } \\
\text { (terrestrial) }\end{array}$ & species $\times$ year & Village-specific & $\begin{array}{l}\text { Chaudhary et al., } \\
\text { (2015) }\end{array}$ \\
\hline $\begin{array}{l}\text { Water use } \\
\text { (distribution) }\end{array}$ & Human health & DALY & Watershed/Indonesia $^{\mathrm{a}}$ & Boulay et al., (2011) \\
\hline Water use & $\begin{array}{l}\text { Ecosystems } \\
\text { (terrestrial) }\end{array}$ & species $\times$ year & Watershed & $\begin{array}{l}\text { ReCiPe2016 } \\
\text { (Huijbregts et al., } \\
\text { 2016), based on Pfister } \\
\text { et al., (2009) }\end{array}$ \\
\hline Water use & $\begin{array}{l}\text { Ecosystems } \\
\text { (freshwater) }\end{array}$ & species $\times$ year & Indonesia $^{\mathrm{b}}$ & $\begin{array}{l}\text { ReCiPe2016 } \\
\text { (Huijbregts et al., } \\
\text { 2016), based on } \\
\text { Hanafiah et al., (2011) }\end{array}$ \\
\hline $\begin{array}{l}\text { Toxicity } \\
\text { (cancer and }\end{array}$ & Human health & DALY & $\begin{array}{l}\text { Outdoor: Southeast Asia } \\
\text { Indoor: household indoor exposure settings based }\end{array}$ & $\begin{array}{l}\text { USEtox } 2.02 \text { (Fantke } \\
\text { et al., 2017a) }\end{array}$ \\
\hline
\end{tabular}




\begin{tabular}{|c|c|c|c|c|}
\hline Impact category & $\begin{array}{l}\text { Area of } \\
\text { protection }\end{array}$ & $\begin{array}{l}\text { Impact score } \\
\text { unit }\end{array}$ & Geographical and temporal reference unit & Reference \\
\hline $\begin{array}{l}\text { non-cancer } \\
\text { effects) }\end{array}$ & & & $\begin{array}{l}\text { on non-OECD archetype combined with village- } \\
\text { specific exposure parameters (see Table S2) }\end{array}$ & \\
\hline $\begin{array}{l}\text { Freshwater } \\
\text { ecotoxicity }\end{array}$ & $\begin{array}{l}\text { Ecosystems } \\
\text { (freshwater) }\end{array}$ & $\begin{array}{l}\text { species } \times \text { year } \\
\text { (converted } \\
\text { from } \\
\mathrm{PDF} \times \mathrm{m} 3 \times \mathrm{d} \text { ) }\end{array}$ & Southeast Asia & $\begin{array}{l}\text { USEtox } 2.02 \text { (Fantke } \\
\text { et al., 2017a) }\end{array}$ \\
\hline $\begin{array}{l}\text { Terrestrial } \\
\text { ecotoxicity }\end{array}$ & $\begin{array}{l}\text { Ecosystems } \\
\text { (terrestrial) }\end{array}$ & $\begin{array}{l}\text { species } \times \text { year } \\
(\text { converted } \\
\text { from } \\
\mathrm{PDF} \times \mathrm{m} 3 \times \mathrm{d})\end{array}$ & $\begin{array}{l}\text { Village-specific for metallic elements; Global for } \\
\text { organic chemicals }\end{array}$ & $\begin{array}{l}\text { ReCiPe2016 } \\
\text { (Huijbregts et al., } \\
\text { 2016); (Owsianiak et } \\
\text { al., 2017; Owsianiak } \\
\text { et al., 2013) for } \\
\text { metallic elements }\end{array}$ \\
\hline $\begin{array}{l}\text { Marine } \\
\text { ecotoxicity }\end{array}$ & $\begin{array}{l}\text { Ecosystems } \\
\text { (marine) }\end{array}$ & $\begin{array}{l}\text { species } \times \text { year } \\
\text { (converted } \\
\text { from } \\
\mathrm{PDF} \times \mathrm{m} 3 \times \mathrm{d} \text { ) }\end{array}$ & $\begin{array}{l}\text { Indonesian Sea marine ecosystem for metallic } \\
\text { elements; Global for organic chemicals }\end{array}$ & $\begin{array}{l}\text { ReCiPe2016 } \\
\text { (Huijbregts et al., } \\
\text { 2016) for organics; } \\
\text { Dong et al., (2016) for } \\
\text { metallic elements }\end{array}$ \\
\hline $\begin{array}{l}\text { Freshwater } \\
\text { eutrophication }\end{array}$ & $\begin{array}{l}\text { Ecosystems } \\
\text { (freshwater) }\end{array}$ & species $\times$ year & Indonesia & $\begin{array}{l}\text { ReCiPe2016 } \\
\text { (Huijbregts et al., } \\
2016 \text { ) }\end{array}$ \\
\hline $\begin{array}{l}\text { Marine } \\
\text { eutrophication }\end{array}$ & $\begin{array}{l}\text { Ecosystems } \\
\text { (marine) }\end{array}$ & species $\times$ year & Village-specific & $\begin{array}{l}\text { Cosme et al., (2017; } \\
\text { Cosme and Hauschild, } \\
\text { 2017); Roy et al., } \\
\text { (2014) }\end{array}$ \\
\hline $\begin{array}{l}\text { Terrestrial } \\
\text { acidification }\end{array}$ & $\begin{array}{l}\text { Ecosystems } \\
\text { (terrestrial) }\end{array}$ & species $\times$ year & Village-specific & $\begin{array}{l}\text { ReCiPe2016 } \\
\text { (Huijbregts et al., } \\
\text { 2016) }\end{array}$ \\
\hline $\begin{array}{l}\text { Photochemical } \\
\text { ozone }\end{array}$ & Human health & DALY & $\begin{array}{l}\text { Region comprising Indonesia, Papua New } \\
\text { Guinea, and East Timor }\end{array}$ & $\begin{array}{l}\text { ReCiPe2016 } \\
\text { (Huijbregts et al., }\end{array}$ \\
\hline
\end{tabular}




\begin{tabular}{|c|c|c|c|c|}
\hline Impact category & $\begin{array}{l}\text { Area of } \\
\text { protection }\end{array}$ & $\begin{array}{l}\text { Impact score } \\
\text { unit }\end{array}$ & Geographical and temporal reference unit & Reference \\
\hline formation & & & & 2016) \\
\hline $\begin{array}{l}\text { Photochemical } \\
\text { ozone } \\
\text { Formation }\end{array}$ & $\begin{array}{l}\text { Ecosystems } \\
\text { (terrestrial) }\end{array}$ & species $\times$ year & $\begin{array}{l}\text { Region comprising Indonesia, Papua New } \\
\text { Guinea, and East Timor }\end{array}$ & $\begin{array}{l}\text { ReCiPe2016 } \\
\text { (Huijbregts et al., } \\
\text { 2016) }\end{array}$ \\
\hline $\begin{array}{l}\text { Mineral } \\
\text { resource } \\
\text { scarcity }\end{array}$ & Resources & USD2013 & Global & $\begin{array}{l}\text { ReCiPe2016 } \\
\text { (Huijbregts et al., } \\
\text { 2016) }\end{array}$ \\
\hline $\begin{array}{l}\text { Fossil resource } \\
\text { scarcity }\end{array}$ & Resources & USD2013 & Global & $\begin{array}{l}\text { ReCiPe2016 } \\
\text { (Huijbregts et al., } \\
\text { 2016) }\end{array}$ \\
\hline
\end{tabular}

\footnotetext{
${ }^{\mathrm{a}}$ although watershed-specific characterization factors were calculated by Boulay et al., (2011) for main watersheds (ca.
} 600 in total), all four villages are located outside main watersheds and thus assigned the same characterization factor ${ }^{\mathrm{b}}$ although watershed-specific characterization factors were calculated by Hanafiah et al., (2011) for well-known river basins above $42^{\circ}$ latitude ( 214 in total), none of the four villages could be mapped on the watershed.

\subsection{Sensitivity and uncertainty analyses}

A sensitivity analysis of the results of the discrete parameters as determined by scenarios presented in Table 1 (Section 2.1) was conducted by comparing impact scores without any internal normalization. For continuous parameters, sensitivity of impact scores was quantified by computing normalized sensitivity coefficients (eq 1), based on Ryberg et al., (2015):

$X_{I S, k}=\frac{\Delta I S / I S}{\Delta a_{k} / a_{k}}$

where $\mathrm{X}_{\mathrm{IS}, \mathrm{k}}$ is the dimensionless normalized sensitivity coefficient of impact score (IS) for perturbance of continuous parameter $\mathrm{k}, \mathrm{a}_{\mathrm{k}}$ is the kth parameter value, $\Delta \mathrm{a}_{\mathrm{k}}$ is the perturbation of parameter $\mathrm{a}_{\mathrm{k}}$, IS is the calculated impact score, and $\Delta \mathrm{IS}$ is the change of the impact score that 
resulted from the perturbation of parameter $\mathrm{a}_{\mathrm{k}}$. Baseline parameter values were used as default in all scenarios listed in Table 1. They originate from measurements and are described in Section 2.2.

Perturbed parameter values representing lower and higher ranges of parameters were defined based on variations reported earlier in other experimental studies on biochar in developing and middleincome countries (Table 3). A parameter is considered important if $X_{\mathrm{IS}, \mathrm{k}} \geq 0.3$, corresponding to a medium sensitivity (Cohen et al., 2013). Uncertainties in those parameters which were found important in the perturbation analysis (see SI, Section S6.5 for results of the sensitivity analysis) were assigned either normal, or triangular, or uniform distributions based on the distribution of measured values (SI, Section S4).

In addition to parameter uncertainties, uncertainties in the life cycle inventories were also considered. For the foreground processes (e.g. in material inputs or emissions) they were estimated using the Pedigree matrix approach, as illustrated in Ciroth et al., (2013) assuming that the data was log-normally distributed (Huijbregts et al., 2003). Uncertainties in the background processes were based on geometric standard deviations already assigned to flows in the ecoinvent processes used. Uncertainties in characterization factors are not provided for the majority of the methods, and were therefore not considered. Monte Carlo simulations (1000 iterations) were carried out for pairwise comparison between scenarios listed in Table 1 while keeping track of the correlations between pairs of systems. Comparisons were considered statistically significant if at least $95 \%$ of all 1000 Monte Carlo runs were favourable for one scenario.

Table 3. Uncertain, continuous model parameters for processes associated with biochar systems. Values referred to as default apply to all relevant scenarios listed in Table 1. Perturbation analysis was carried out to test the influence of a parameter value on the results for selected scenarios.

\begin{tabular}{|l|l|l|l|l|}
\hline \multirow{2}{*}{ Parameter } & \multicolumn{2}{|l|}{ Parameter values } & Unit & Source \\
\cline { 2 - 3 } & Default & Perturbation & & \\
\hline
\end{tabular}




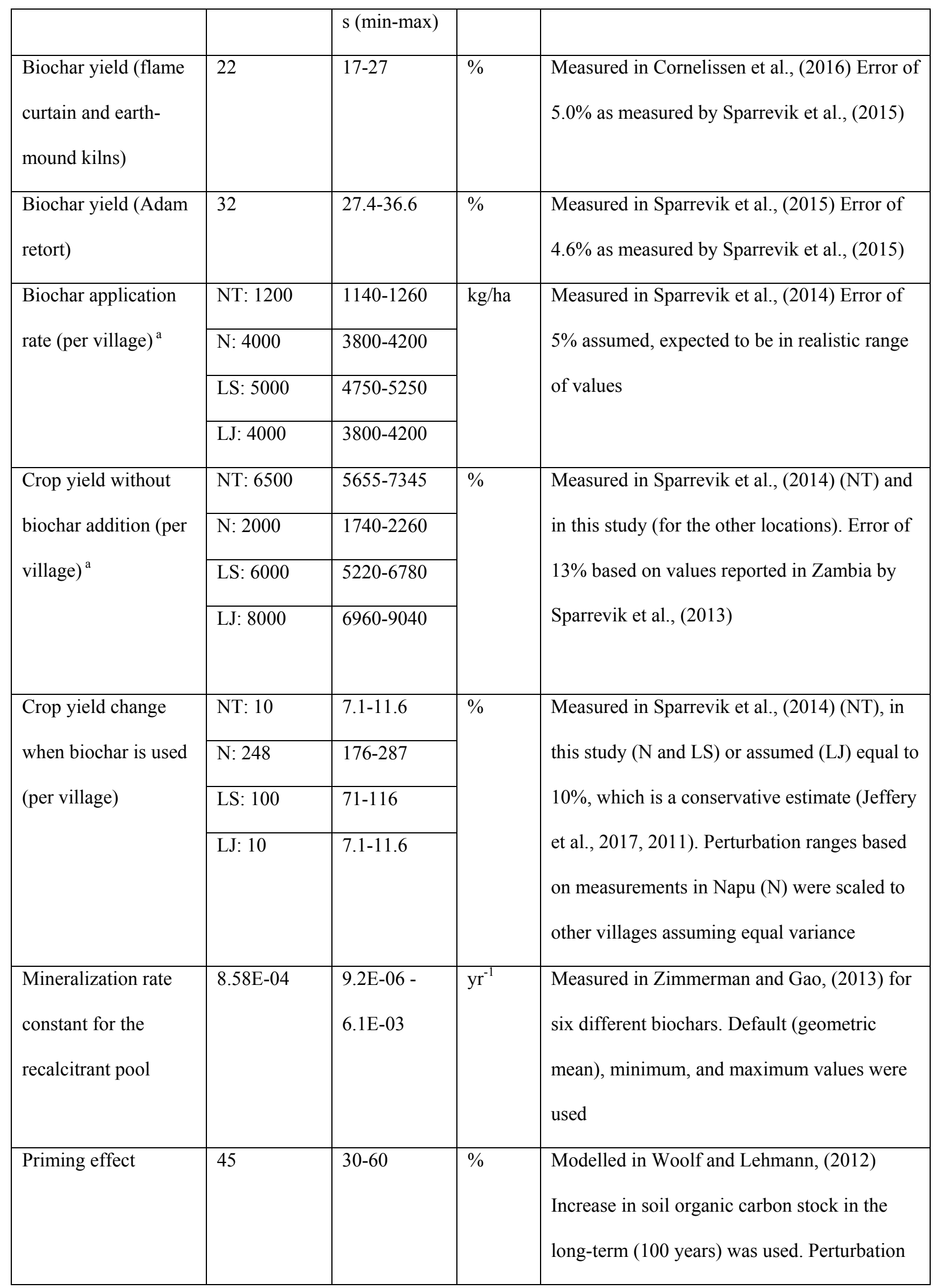




\begin{tabular}{|c|c|c|c|c|}
\hline & & & & $\begin{array}{l}\text { values are ranges reported (Woolf and } \\
\text { Lehmann, 2012) }\end{array}$ \\
\hline \multirow{4}{*}{$\begin{array}{l}\text { Water use for } \\
\text { irrigation (per } \\
\text { village) }^{\text {a }}\end{array}$} & NT: 0.155 & $0.11-0.20$ & \multirow{4}{*}{$\begin{array}{l}\mathrm{m}^{3} / \mathrm{kg} \\
\text { output }\end{array}$} & \multirow{4}{*}{$\begin{array}{l}\text { Measured in this study. Perturbation values } \\
\text { assumed } 30 \% \text { increased and decrease, which } \\
\text { is in realistic range of values }\end{array}$} \\
\hline & $\mathrm{N}: 0$ & $0-0$ & & \\
\hline & LS: 0.155 & $0.11-0.20$ & & \\
\hline & LJ: 0.155 & $0.11-0.20$ & & \\
\hline $\begin{array}{l}\text { Fraction of PM } \\
\text { smaller than } 2.5 \mu \mathrm{m}\end{array}$ & 0.92 & $0.73-0.95$ & $\mathrm{~kg} / \mathrm{kg}$ & $\begin{array}{l}\text { Measured for residential wood combustion as } \\
\text { reported in Humbert et al., (2011) Value of } \\
0.73 \text { is for low-stack emissions, value of } 0.95 \\
\text { is in higher range of measured values for } \\
\text { various sources (Humbert et al., 2011) }\end{array}$ \\
\hline
\end{tabular}

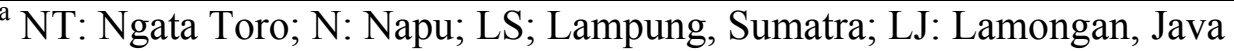




\section{Results}

\subsection{Comparison between generic and spatially differentiated impacts}

263

Figure 2 shows the comparison between generic and spatially differentiated impacts from biochar produced using a flame curtain kiln and used in agriculture, as influenced by geographic location of the field and fertilizer type (scenarios 1-4 and 13-15 in Table 1). Impact scores for individual impact categories either increased or decreased compared with generic scores, depending on the impact category (see also SI, Section S6.1). The largest consistent increase (by ca. 2 orders of magnitude) was observed at all locations for the human health impacts from water use (except Napu). Spatially differentiated characterization factors for human health impacts in the watersheds are equal to $0 \mathrm{DALY} / \mathrm{m}^{3}$ for all sites except Napu where the characterization factor is higher and reflects water scarcity problems on Sumba. However, current agricultural practice does not rely on irrigation in this village. This explains why there are no apparent benefits in terms of water used impacts when the system is credited for increasing crop yields in Napu for both spatially differentiated and generic assessments. The comparison between spatially differentiated and generic impacts also shows that there is some reduction in human health impacts stemming from emissions of PM2.5 (difference up to factor of 2), mainly because the site-specific intake of PM2.5 resulting from emissions are smaller at the site-specific level at these rural sites, than the default value used in global-generic assessment.

The largest consistent decrease when spatial differentiation was used (by ca. 1 order of magnitude) was observed at all locations for land use impacts on birds and mammals. Indonesian ecoregions are among the most biodiverse globally, and characterization factors are generally one order of magnitude higher in all villages when compared to global-generic values (Chaudhary et al., 2015). Changes in impact scores for other impact categories ranged from small (below 10\%) to large (up to a factor of 5) when spatial differentiation was considered, but these differences were 
largely non-conspicuous as the contribution of these impacts categories to total damage was often very small (less than $1 \%$ of total damage). Statistically significant differences between regionalized and generic impacts were found in nearly all impact categories, except for freshwater eutrophication. Similar trends were observed for other kilns (see SI, Section S6.2). The major differences between spatially differentiated and generic impacts were, again, due to significantly smaller (but not equal to zero) contributions from water use impacts on the terrestrial ecosystem (Fig. 2b). Here, the very high resolution of watersheds used in the method of Pfister et al., (2009) which includes relevant minor watersheds, allowed each village and its corresponding watershed to be mapped. In addition, there was an increase in impact scores for terrestrial acidification due to a small alkaline buffering capacity of the soils, making them more vulnerable to acidic emissions. Figure $2 \mathrm{~b}$ also shows that there is some reduction in ecotoxicological impacts stemming from using soil-specific characterization factors for metallic elements (like $\mathrm{Cd}$ or $\mathrm{Zn}$ ) emitted together with fertilizer as co-contaminants. Terrestrial ecotoxicity characterization factors for these elements are generally higher (approximately twice as high) compared to generic values because acidic soils have a higher bioavailable metal concentration and thus a higher toxicity potentials in soils (Owsianiak et al., 2017; Owsianiak et al., 2015).

When aggregating impacts at the human health and ecosystem level, the impact of spatial differentiation was less pronounced. The spatially differentiated damage to human health was approximately 3 to 5 times higher when compared to generic scores, except for Napu where total damage was comparable between approaches (Fig. 2a). For aggregated potential impacts on ecosystems, the effect of spatial differentiation was not significant (Fig. 2b), although impact scores varied by up to one order of magnitude for the individual impact categories. This is mainly caused by the small absolute numbers for the impact categories mostly influenced by spatial differentiation (such as marine eutrophication or ozone formation) (see SI, Section S6.1), as well as trade-offs 
between categories, where an increase in impact scores for some categories was compensated by a decrease in others. For example, the increase in impact from water use and acidification in the regionalized assessment was compensated by increased benefits from land use impacts on plants. These benefits roughly doubled when compared with the global-generic assessment. Fig. 2.

\section{Discussion}

\subsection{Relevance of spatial differentiation for decision support}

Results presented in Fig. 2 and in Section S6.1 of the SI show that spatially differentiated impact assessments resulted in more accurate and realistic results than generic assessments. This finding is consistent with earlier regionalized LCA studies demonstrating the use of spatially differentiated LCIA methods. Mutel et al., (2011) already showed that spatially differentiated ecosystem damage and human health scores of coal-based power generation in America were 30\% higher and 38\% lower, respectively, compared to generic scores. Anton et al., (2014) reported that regionalized human toxicity impacts of tomato agriculture in Spain were one order of magnitude higher than those determined from generic assessment. More recently, Henderson et al., (2017) demonstrated that spatial differentiation resulted in a nearly double water stress for American food production when compared to a generic assessment.

This is the first regionalized comparative LCA study where influence of spatial differentiation on decision support was investigated. While this study corroborates earlier regionalized LCA studies in terms of influence of spatial differentiation on impact scores, it demonstrates that the benefits of spatial differentiation for decision-support are closely connected to 
the goal of the LCA. The discussion below therefore relates to various aspects in a decision support context, using the application of biochar technology as the example.

\subsubsection{Evaluation at an absolute scale}

In order to make decisions about the implementation of a new biowaste management strategy, information about overall environmental performance of the technology is needed. In this study, impact scores were negative in most (but not all) of the individual impact categories, and the total damages were all negative (Fig. 2). Thus, environmental benefits from increased crop productivity outweighed the environmental burden of biochar production, which can include human health impacts from particulate matter and emission of toxic carcinogenic compounds. This holds true for all of the geographic locations, biochar production techniques, and fertilizers compared, suggesting that spatial differentiation does not influence decisions about implementing biochar systems in Indonesia. This study showed that a crop productivity increase as low as $10 \%$, such as in Lampung and Ngata Toro (and lower than $25 \%$ as reported in a recent meta-analysis for tropical soils (Jeffery et al., 2017), is sufficient to make spatial differentiation irrelevant with regards to making decisions about the implementation of biochar-based management strategy for biowaste in Indonesia. Burden and benefits can also be determined by the current waste management practice that is replaced by the new biowaste management strategy (Owsianiak et al., 2016). In the biochar context, spatial differentiation is therefore expected to be less relevant in cases where the replaced waste management system is based on the polluting methods composting or landfilling, which emit the potent greenhouse gas methane (Laurent et al., 2014).

The increase in crop productivity of $10 \%$ may, however, be sufficient to make spatial differentiation relevant for certain chars where production and/or transportation to the field are important contributors to total impacts, as has been shown to be the case for hydrochars (Owsianiak et al., 2017). This may also hold true for biochars made on an industrial scale (and thus off-site). It 
is therefore important to see spatial differentiation in connection to the quality of the inventory, which for most relevant processes in this study used site-specific data.

\subsubsection{Relative ranking}

One plausible management decision from the LCA would be a relative feasibility ranking of villages to assess the benefit of implementing biochar technology in that specific region. For human health damage, both generic and spatially differentiated assessments identified Lampung as the village performing best, while Napu and Ngata Toro/Lamongan were identified as least optimal in both the generic and site-specific assessments (Fig. 3 and SI, Section 6.3). This difference is due to different quantities of water used for irrigation. Further, different villages were identified as best in scenarios with alternative fertilization strategies. This makes spatial differentiation relevant to consider in cases where detailed rank information is desirable. For total ecosystem damage however, Lampung and Lamongan performed best in both generic and spatially differentiated assessments, with no statistically significant difference between them. This was mainly due relatively large geographic differences in life cycle inventories between villages, which were larger than geographic differences in characterization factors. Indeed, the good performance of Napu (relative to the other villages) is explained by the very high productivity increase when biochar is amended to soils ( $250 \%$ increase compared to the control; Table 2$)$. The relatively good performance of Lampung is explained by the high productivity increase $(100 \%$ increase compared to the control; Table 2) which in turn reduces the need for inorganic fertilizers, combined with the fact that the absolute yield was relatively high for agricultural practices without biochar.

To isolate the effects of variability in life cycle inventories from spatial differences in characterization factors, inventory flows in all villages were set to be the same, and equal to that of Ngata Toro. Spatially differentiated LCA carried out showed that a different village performed best 
when considering total damage to human health (Lamongan, against Lampung for site-specific inventories) (Table S36). This further emphasizes that differences in ranking between villages were mainly caused by variability in life cycle inventories between villages. Henderson et al., (2017) also showed that in addition to spatial differences in characterization factors, variability in inventories of water used for irrigation explained a large part of the differences in water deprivation impacts from corn production and from milk production between different geographic locations within the U.S.

\subsubsection{Process contribution}

Finally, decision makers are interested in identifying improvement options in the biochar life cycle. At the total damage level, spatial differentiation was generally not important in determining which processes contributed most to overall benefits (here, agricultural benefits from increasing yields or sequestration and storage of carbon). Only in one case (scenario 1) were the largest benefits attributed to increases in crop productivity in the generic assessment, while both the productivity increase and biochar production (specifically, sequestration of carbon) contributed nearly equally to human health benefits in regionalized assessment (SI, Section 6.4). However, spatial differentiation did influence the identification of processes with the largest environmental burdens in some individual impact categories. For example, it identified biochar use as a major driver of freshwater eutrophication (due to direct emissions of phosphorus together with the biochar added to soil) in the generic assessment, while in the spatially differentiated assessment the contribution of this process was smaller and comparable to that of biochar production. Thus, spatial differentiation could still be relevant to support decision about improving environmental performance of a given biochar system by suggesting changes in processes which decision-makers have influence on (foreground processes). In this particular case, the decision-maker could focus on reducing $\mathrm{P}$ emissions by using biochar with smaller content of $\mathrm{P}$, but more accurate and realistic assessment of environmental 
impacts as offered by spatially differentiated impact assessment is needed to determine whether such improvement is valuable.

Fig. 3.

\subsection{Practical implications}

This study corroborates earlier studies showing that spatial differentiation is particularly relevant in cases where geographic variability in characterization factors is large (e.g., land or water use), and where total impact is dominated by one or few flows contributing to that impact category (e.g. irrigation or land occupation) (Chaudhary et al., 2016; Henderson et al., 2017b). As product life cycles are global, emissions in the life cycles can occur anywhere, making spatially differentiated LCA the preferred option if accuracy and realism of impacts are important for the goal of the LCA. This includes cases where the intended application is identification of weak points in the product system as a basis for environmental optimization. In this case, different conclusions were drawn related to potential improvement options in the biochar system to address eutrophication impacts on freshwater ecosystems.

Due to trade-offs between burden and benefits spatial differentiation had no relevance for decisions related to whether a new biochar-based waste management strategy should be implemented. Thus, in this aspect of the goal definition, spatial differentiation in LCIA did not lead to better decision support. This conclusion is expected to hold for systems where environmental benefits largely outweigh burdens, including the use of other chars in agriculture (Owsianiak et al., 2017) or technologies which replace inefficient waste management systems or allow reducing food losses (Fabbri et al., 2018).

Large geographic variability in life cycle inventories, combined with trade-offs between impact categories, resulted in spatial differentiation having a limited relevance for decisions about 
identification of best biochar production techniques and agricultural use conditions for ecosystem damage. Heidari et al., (2017) also showed that for pasta production in Iran the impact of ozone formation was up to a factor two larger than the generic determined impact, while impacts for land use and acidification were up to a factor of three smaller. Trade-offs between impact categories like those presented in this study and earlier in Heidari et al., (2017) are expected to occur for other product systems if they are located in dry and not very biodiverse regions (e.g. Iran), or in waterrich and biodiverse areas (like the majority of the Indonesian islands). However, in less extreme conditions with regard to water availability and biodiversity status (e.g. in Europe), similar tradeoffs may not occur, and other impact categories may become dominant contributors (e.g. marine eutrophication impacts in Baltic Sea are expected to be higher compared with the Indonesian Sea marine ecosystems) (Cosme et al., 2017). Further, tradeoffs between impact categories were less relevant for total damage to human health. In addition, species can be weighted differently in LCIA, influencing trade-offs between impact categories (Verones et al., 2015). Thus, spatial differentiation is recommended to be considered as a default approach in comparative LCA studies.

\subsection{Limitations of the study}

Execution of this case study required implementation of regionalized characterization factors for most impact categories into the modelling software employed (SimaPro) and a subsequent matching of them with regionalized input and output flows. This practice, although perhaps the most straightforward from the LCA practitioner's perspective, has some limitations.

Uncertainties in characterization factors were not considered due to incomplete knowledge related to them and the limited ability of the modelling software to consider them. If these uncertainties had been considered, the number of pairwise comparisons with statistically significant differences between regionalized and generic assessments is expected to be smaller. It is a challenge for LCA practitioners to determine whether uncertainties in characterization factors combined with 
inventory and parameter uncertainties are larger than geographic variability in life cycle inventories. Henderson et al., (2017) showed that for water use impacts, spatial variability may be larger than uncertainty.

The second limitation is that the selection of the spatial scale for the impact assessment was based on a simple method of matching regionalized inventories with available respective characterization factors at the smallest scale possible. This limitation is not expected to influence conclusions because geographic locations of each village are accurate and because locations of respective ecoregions, watersheds and agricultural fields corresponding to each village were known. This allowed for both accurate and precise quantification of impacts for relevant impact categories, including water use, land use, and ecotoxicity emissions. Thus, aggregating grid-specific characterization factors in these categories, as proposed by Mutel et al., (2011) is not expected to reduce uncertainty in this case study. Selection of appropriate spatial scale of impact assessment could be relevant however, for some regional impact categories such as freshwater eutrophication. In this case eutrophication relied on the use of country-specific characterization factors, but this impact category was not important contributor to total damage.

\section{Conclusions}

This first regionalized LCA study where spatially differentiated LCIA methods were consistently applied to all relevant impact categories at damage level level showed that although spatial differentiation improved accuracy and realism of environmental impacts, it did not necessarily lead to better decisions. This finding was unexpected considering that conditions in Indonesia with regard to biodiversity are very different compared to generic conditions. Geographic variability in life cycle inventories, combined with small contribution of some impact categories to total damage 
and tradeoffs between impact categories influenced the role of spatial differentiation for decisionsupport in this case study.

Although extrapolation of these findings to other cases is not straightforward, this study may suggest that depending on the goal of the LCA, practitioners should consider potential benefits of implementing spatially differentiated LCIA methods as opposed to potential benefits from collecting site-specific inventories. This study indicates that the former should be the priority in studies where accuracy and realism are required (e.g. in weak point analyses and eco-design LCA studies), but also in comparative LCA studies, while the latter should be the priority in studies where environmental performance of a system is expected to be mainly determined by trade-offs between burden and benefits.

The findings presented in this study raise several additional questions. First, it is unknown whether environmental benefits from implementation of biochar systems are larger than environmental burdens in other regions of the World. Second, it is unknown whether the findings generally apply to other comparative LCA case studies. Third, an intelligent approach needs to be developed to determine which of the flows in the foreground system are relevant to consider for spatially differentiated impact assessments, and which can be omitted. Forth, in this study, spatial differentiation was considered for all flows in the foreground system, but this can be challenging if more complex systems are modelled. Finally, the use of spatially differentiated LCIA methods depends on the ability of LCA modelling software to consider them, and solutions are needed to enable easy and consistent use of spatially differentiated LCIA methods in LCA of products and systems in the future.

\section{Supplementary material}


Details of case studies, model parameters, unit processes, details of uncertainty analysis, details of LCIA methods, and additional results.

\section{Acknowledgements}

This project was funded by the Norwegian Research Council under the Klimaforsk program, project 243789, "Biochar as an adaptation strategy for climate change". Alexis Laurent and Michael Hauschild (DTU) are acknowledged for their advice about selection and use of LCIA methods and interpretation of results. Pierre-Olivier Roy (CIRAIG), Nuno Cosme (Nueva Pescanova, S.L.) and Peter Fantke (DTU) are acknowledged for their assistance with implementing characterization factors.

\section{References}

Adam, J.C., 2009. Improved and more environmentally friendly charcoal production system using a low-cost retort-kiln (Eco-charcoal). Renew. Energy 34, 1923-1925. doi:10.1016/j.renene.2008.12.009

Anton, A., Torrellas, M., Mun, P., Montero, J.I., 2014. Improvement of Agricultural Life Cycle Assessment Studies through Spatial Differentiation and New Impact Categories: Case Study on Greenhouse Tomato Production. Env. Sci Technol 48, 9454-9462.

Bjørn, A., Laurent, A., Owsianiak, M., Olsen, S.I., 2018a. Goal Definition, in: Hauschild, M.Z., Rosenbaum, R.K., Olsen, S.I. (Eds.), Life Cycle Assessment: Theory and Practice. Springer International Publishing, Cham, pp. 67-74. doi:10.1007/978-3-319-56475-3_7

Bjørn, A., Owsianiak, M., Laurent, A., Olsen, S.I., Corona, A., Hauschild, M.Z., 2018b. Scope Definition, in: Hauschild, M.Z., Rosenbaum, R.K., Olsen, S.I. (Eds.), Life Cycle Assessment: Theory and Practice. Springer International Publishing, Cham, pp. 75-116. doi:10.1007/978-3- 
Boulay, A., Bulle, C., Deschênes, L., Margni, M., 2011. Regional Characterization of Freshwater Use in LCA: Modeling Direct Impacts on Human Health. Env. Sci Technol 45, 8948-8957. doi:10.1021/es1030883

Bulle, C., Jolliet, O., Humbert, S., Rosenbaum, R.K., Margni, M., 2012. IMPACT World+: A new global regionalized life cycle impact assessment method., in: Proceedings of the International Conference on Ecobalance, Yokohama, Japan.

Chaudhary, A., Pfister, S., Hellweg, S., 2016. Spatially Explicit Analysis of Biodiversity Loss Due to Global Agriculture, Pasture and Forest Land Use from a Producer and Consumer Perspective. Environ. Sci. Technol. 50, 3928-3936. doi:10.1021/acs.est.5b06153

Chaudhary, A., Verones, F., De Baan, L., Hellweg, S., 2015. Quantifying Land Use Impacts on Biodiversity: Combining Species-Area Models and Vulnerability Indicators. Environ. Sci. Technol. 49, 9987-9995. doi:10.1021/acs.est.5b02507

Cherubini, F., Huijbregts, M., Kindermann, G., Van Zelm, R., Van Der Velde, M., Stadler, K., Strømman, A.H., 2016. Global spatially explicit CO2 emission metrics for forest bioenergy. Sci. Rep. 6, 20186. doi:10.1038/srep20186

Ciroth, A., Muller, S., Weidema, B., Lesage, P., 2013. Empirically based uncertainty factors for the pedigree matrix in ecoinvent. Int. J. Life Cycle Assess. 1-11. doi:10.1007/s11367-013-0670-5

Cohen, J., Cohen, P., West, S.G., Aiken, L.S., 2013. Applied Multiple Regression/Correlation Analysis for the Behavioral Sciences. Taylor \& Francis.

Commission, E., 2010. ILCD Handbook: General guide for Life Cycle Assessment - Detailed 
guidance.

Cornelissen, G., Pandit, N.R., Taylor, P., Pandit, B.H., Sparrevik, M., Schmidt, H.P., 2016. Emissions and Char Quality of Flame-Curtain "Kon Tiki” Kilns for Farmer-Scale Charcoal/Biochar Production. PLoS One 11, e0154617. doi:10.1371/journal.pone.0154617

Cosme, N., Hauschild, M.Z., 2017. Characterization of waterborne nitrogen emissions for marine eutrophication modelling in life cycle impact assessment at the damage level and global scale. Int. J. Life Cycle Assess. 1-13. doi:10.1007/s11367-017-1271-5

Cosme, N., Jones, M.C., Cheung, W.W.L., Larsen, H.F., 2017. Spatial differentiation of marine eutrophication damage indicators based on species density. Ecol. Indic. 73, 676-685. doi:10.1016/j.ecolind.2016.10.026

Dong, Y., Rosenbaum, R.K., Hauschild, M.Z., 2016. Assessment of metal toxicity in marine ecosystems - Comparative Toxicity Potentials for nine cationic metals in coastal seawater. Environ. Sci. Technol. 50, 269-278. doi:10.1021/acs.est.5b01625

European Comission for Standardization, 2006a. ISO 14040:2006 - Environmental management Life cycle assessment - Principles and framework. doi:10.1136/bmj.332.7550.1107

European Comission for Standardization, 2006b. ISO 14044 - Environmental management - Life cycle assessment - Requirements and guidelines - ISO 14044 46. doi:10.1007/s11367-0110297-3

Fabbri, S., Olsen, S.I., Owsianiak, M., 2018. Improving environmental performance of post-harvest supply chains of fruits and vegetables in Europe: Potential contribution from ultrasonic humidification. J. Clean. Prod. 182, 16-26. doi:https://doi.org/10.1016/j.jclepro.2018.01.157 
Fantke, P., Bijster, M., Guignard, C., Hauschild, M., Huijbregts, M., Jolliet, O., Kounina, A., Magaud, V., Margni, M., McKone, T., Posthuma, L., Rosenbaum, R.K., van de Meent, D., van Zelm, 2, R., 2017a. USEtox ${ }^{\circledR} 2.0$, Documentation version 1. doi:10.11581/DTU:00000011

Fantke, P., Jolliet, O., Apte, J.S., Hodas, N., Evans, J., Weschler, C.J., Stylianou, K.S., Jantunen, M., McKone, T.E., 2017b. Characterizing Aggregated Exposure to Primary Particulate Matter: Recommended Intake Fractions for Indoor and Outdoor Sources. Environ. Sci. Technol. 51, 9089-9100. doi:10.1021/acs.est.7b02589

Galgani, P., Delft, T.U., 2012. Composting, Anaerobic Digestion and Biochar in Ghana, in the Context of Voluntary Carbon Markets. Waste Manag. 2011, 2454-2465. doi:10.1016/j.wasman.2014.07.027

Gwenzi, W., Chaukura, N., Mukome, F.N.D., Machado, S., Nyamasoka, B., 2015. Biochar production and applications in sub-Saharan Africa: Opportunities, constraints, risks and uncertainties. J. Environ. Manage. doi:10.1016/j.jenvman.2014.11.027

Hanafiah, M.M., Xenopoulos, M.A., Pfister, S., Leuven, R.S.E.W., Huijbregts, M.A.J., 2011. Characterization Factors for Water Consumption and Greenhouse Gas Emissions Based on Freshwater Fish Species Extinction. Environ. Sci. Technol. 45, 5272-5278. doi:10.1021/es1039634

Hauschild, M.Z., Huijbregts, M.A.J., 2015. Life cycle impact assessment. doi:10.1007/BF02978760

Heidari, M.D., Huijbregts, M.A.J., Mobli, H., Omid, M., Rafiee, S., van Zelm, R., 2017. Regionalised life cycle assessment of pasta production in Iran: Damage to terrestrial ecosystems. J. Clean. Prod. 159, 141-146. doi:10.1016/j.jclepro.2017.05.073

Henderson, A.D., Asselin-Balençon, A.C., Heller, M., Lessard, L., Vionnet, S., Jolliet, O., 2017 a. 
Spatial Variability and Uncertainty of Water Use Impacts from U.S. Feed and Milk Production. Environ. Sci. Technol. 51, 2382-2391. doi:10.1021/acs.est.6b04713

Henderson, A.D., Asselin-Balençon, A.C., Heller, M.C., Lessard, L., Vionnet, S., Jolliet, O., 2017b. Spatial variability and uncertainty of water use impacts from US feed and milk production. Environ. Sci. Technol. 51, 2382-2391. doi:10.1021/acs.est.6b04713

Huijbregts, M.A.J., Gilijamse, W., Ragas, A.M.J., Reijnders, L., 2003. Evaluating Uncertainty in Environmental Life-Cycle Assessment. A Case Study Comparing Two Insulation Options for a Dutch One-Family Dwelling. Environ. Sci. Technol. 37, 2600-2608. doi:10.1021/es020971+

Huijbregts, M.A.J., Steinmann, Z.J.N., Elshout, P.M.F., Stam, G., Verones, F., Vieira, M., Zijp, M.C., Hollander, A., van Zelm, R., 2016. ReCiPe2016 : a harmonized life cycle impact assessment method at midpoint and endpoint level. Int. J. Life Cycle Assess. 1-152. doi:10.1007/s11367-016-1246-y

Humbert, S., Marshall, J.D., Shaked, S., Spadaro, J. V, Nishioka, Y., Preiss, P., McKone, T.E., Horvath, A., Jolliet, O., 2011. Intake Fraction for Particulate Matter: Recommendations for Life Cycle Impact Assessment. Environ. Sci. Technol. 45, 4808-4816. doi:10.1021/es103563z

IPCC, Stocker, T.F., Qin, D., Plattner, G.-K., Tignor, M.M.B., Allen, S.K., Boschung, J., Nauels, A., Xia, Y., Bex, V., Midgley, P.M., 2013. Climate Change 2013 - The Physical Science Basis, Intergovernmental Panel on Climate Change. doi:10.1038/446727a

Jeffery, S., Abalos, D., Prodana, M., Bastos, A.C., Van Groenigen, J.W., Hungate, B.A., Verheijen, F., 2017. Biochar boosts tropical but not temperate crop yields. Environ. Res. Lett. 12. doi:10.1088/1748-9326/aa67bd

Jeffery, S., Verheijen, F.G. a, van der Velde, M., Bastos, a. C., 2011. A quantitative review of the 
603

604

605

606

607

608

609

610

611

612

613

614

615

616

617

618

619

620

621

622

623

624

effects of biochar application to soils on crop productivity using meta-analysis. Agric. Ecosyst. Environ. 144, 175-187. doi:10.1016/j.agee.2011.08.015

Laurent, A., Bakas, I., Clavreul, J., Bernstad, A., Niero, M., Gentil, E., Hauschild, M.Z., Christensen, T.H., 2014. Review of LCA studies of solid waste management systems - Part I: Lessons learned and perspectives. Waste Manag. 34, 573-588. doi:10.1016/j.wasman.2013.10.045

Lehmann, J., 2007. A handful of carbon. Nature 447, 143-144. doi:10.1038/447143a

Levasseur, A., Lesage, P., Margni, M., Deschênes, L., Samson, R., 2010. Considering time in LCA: dynamic LCA and its application to global warming impact assessments. Environ. Sci. Technol. 44, 3169-74. doi:10.1021/es9030003

Mutel, C.L., Pfister, S., Hellweg, S., 2011. GIS-Based Regionalized Life Cycle Assessment: How Big Is Small Enough? Methodology and Case Study of Electricity Generation. Environ. Sci. Technol. 46, 1096-1103. doi:10.1021/es203117z

Nsamba, H.K., Hale, S.E., Cornelissen, G., Bachmann, R.T., 2015. Sustainable Technologies for Small-Scale Biochar Production-A Review. J. Sustain. Bioenergy Syst. 05, 10-31. doi:10.4236/jsbs.2015.51002

Owsianiak, M., Brooks, J., Renz, M., Laurent, A., 2017. Evaluating climate change mitigation potential of hydrochars: Compounding insights from three different indicators. GCB Bioenergy. doi:10.1111/gcbb.12484

Owsianiak, M., Holm, P.E., Fantke, P., Christiansen, K.S., Borggaard, O.K., Hauschild, M.Z., 2015. Assessing comparative terrestrial ecotoxicity of $\mathrm{Cd}, \mathrm{Co}, \mathrm{Cu}, \mathrm{Ni}, \mathrm{Pb}$, and $\mathrm{Zn}$ : The influence of aging and emission source. Environ. Pollut. 206, 400-410. doi:10.1016/j.envpol.2015.07.025 
Owsianiak, M., Huijbregts, M., Hauschild, M.Z., 2017. Improved comparative toxicity potentials of 626

627

628

629

630

631

632

633

634

635

636

637

638

639

640

641

642

643

644

645

646

23 metallic elements in soils: addressing solid- and liquid-phase speciation in environmental fate, exposure, and effects, in: Book of Abstracts, SETAC Europe 27tt Annual Meeeting. Brussels, Belgium, 7-11 May 2017.

Owsianiak, M., Rosenbaum, R.K., Huijbregts, M.A.J., Hauschild, M.Z., 2013. Addressing geographic variability in the comparative toxicity potential of copper and nickel in soils. Environ. Sci. Technol. 47, 3241-3250.

Owsianiak, M., Ryberg, M.W., Renz, M., Hitzl, M., Hauschild, M.Z., 2016. Environmental Performance of Hydrothermal Carbonization of Four Wet Biomass Waste Streams at IndustryRelevant Scales. ACS Sustain. Chem. Eng. 4. doi:10.1021/acssuschemeng.6b01732

Patouillard, L., Bulle, C., Querleu, C., Maxime, D., Osset, P., Margni, M., 2018. Critical review and practical recommendations to integrate the spatial dimension into life cycle assessment. J. Clean. Prod. 177, 398-412. doi:10.1016/j.jclepro.2017.12.192

Pfister, S., Koehler, A., Hellweg, S., 2009. Assessing the environmental impacts of freshwater consumption in LCA. Environ. Sci. Technol. 43, 4098-4104. doi:10.1021/es802423e

Potting, Jose; Hauschild, M., 2006. Spatial Differentiation in Life Cycle Impact Assessment: A decade of method development to increase the environmental realism of LCIA. Int. J. Life Cycle Assess. 11, 11-13. doi:10.1065/lca2006.04.005

Rosenbaum, R.K., 2018. Overview of Existing LCIA Methods---Annex to Chapter 10, in: Hauschild, M.Z., Rosenbaum, R.K., Olsen, S.I. (Eds.), Life Cycle Assessment: Theory and Practice. Springer International Publishing, Cham, pp. 1147-1183. doi:10.1007/978-3-319$56475-3$ 
Rosenbaum, R.K., Hauschild, M.Z., Boulay, A.-M., Fantke, P., Laurent, A., Núñez, M., Vieira, M., 2018. Life Cycle Impact Assessment, in: Hauschild, M.Z., Rosenbaum, R.K., Olsen, S.I. (Eds.), Life Cycle Assessment: Theory and Practice. Springer International Publishing, Cham, pp. 167-270. doi:10.1007/978-3-319-56475-3_10

Roy, P.O., Azevedo, L.B., Margni, M., van Zelm, R., Deschênes, L., Huijbregts, M.A.J., 2014. Characterization factors for terrestrial acidification at the global scale: A systematic analysis of spatial variability and uncertainty. Sci. Total Environ. 500-501, 270-276. doi:10.1016/j.scitotenv.2014.08.099

Ryberg, M.W., Owsianiak, M., Laurent, A., Hauschild, M.Z., 2015. Power generation from chemically cleaned coals: do environmental benefits of firing cleaner coal outweigh environmental burden of cleaning? Energy Environ. Sci. 2435-2447. doi:10.1039/C5EE01799H

Schmidt, H., Taylor, P., Eglise, A., Arbaz, C.-, 2014. Kon-Tiki flame curtain pyrolysis for the democratization of biochar production. Biochar J. 14-24.

Sparrevik, M., Cornelissen, G., Sparrevik, M., Adam, C., Martinsen, V., Cornelissen, G., Cornelissen, G., 2015. Emissions of gases and particles from charcoal/biochar production in rural areas using medium-sized traditional and improved "retort" kilns. Biomass and Bioenergy 72, 65-73. doi:10.1016/j.biombioe.2014.11.016

Sparrevik, M., Field, J.L., Martinsen, V., Breedveld, G.D., Cornelissen, G., 2013. Life cycle assessment to evaluate the environmental impact of biochar implementation in conservation agriculture in Zambia. Environ. Sci. Technol. 47, 1206-15. doi:10.1021/es302720k 

Socioeconomic Impacts of Utilizing Waste for Biochar in Rural Areas in Indonesia-A Systems Perspective. Environ. Sci. Technol. 48, 4664-4671. doi:10.1021/es405190q

Verones, F., Bare, J., Bulle, C., Frischknecht, R., Hauschild, M., Hellweg, S., Henderson, A., Jolliet, O., Laurent, A., Liao, X., Lindner, J.P., Maia de Souza, D., Michelsen, O., Patouillard, L., Pfister, S., Posthuma, L., Prado, V., Ridoutt, B., Rosenbaum, R.K., Sala, S., Ugaya, C., Vieira, M., Fantke, P., 2017. LCIA framework and cross-cutting issues guidance within the UNEP-SETAC Life Cycle Initiative. J. Clean. Prod. 161, 957-967. doi:10.1016/j.jclepro.2017.05.206

Verones, F., Hellweg, S., Azevedo, L.B., Laurent, A., Mutel, C.L., Pfister, S., 2016. LC-Impact.

Verones, F., Huijbregts, M.A.J., Chaudhary, A., de Baan, L., Koellner, T., Hellweg, S., 2015. Harmonizing the Assessment of Biodiversity Effects from Land and Water Use within LCA. Environ. Sci. Technol. 49, 3584-3592. doi:10.1021/es504995r

Weidema, B.P., Bauer, C., Hischier, R., Mutel, C.L., Nemecek, T., Reinhard, J., Vadenbo, C.O., Wernet, G., 2013. Data quality guidelines for the ecoinvent database version 3: Overview and methdology (final), The International Journal of Life Cycle Assessment.

Woolf, D., Amonette, J.E., Street-Perrott, F.A., Lehmann, J., Joseph, S., 2010. Sustainable biochar to mitigate global climate change. Nat. Commun. 1, 56. doi:10.1038/ncomms 1053

Woolf, D., Lehmann, J., 2012. Modelling the long-term response to positive and negative priming of soil organic carbon by black carbon. Biogeochemistry 111, 83-95. doi:10.1007/s10533-0129764-6

Zimmerman, A., Gao, B., 2013. The Stability of Biochar in the Environment, in: Biochar and Soil Biota. CRC Press, pp. 1-40. doi:doi:10.1201/b14585-2 
Fig. 1. System boundaries for treatment of biogenic carbon with use of biochar as soil conditioner to support crop productivity. The functional unit was defined as "treatment of $1 \mathrm{~kg}$ of biogenic carbon from biomass residues in rural areas in Indonesia”. Dashed lines indicate avoided processes.

Fig. 2. Generic and spatially differentiated damage to human health (a) and ecosystems (b) from biochar production using flame curtain kiln and its use for improving agriculture in Indonesia, as influenced by geographic location and fertilizer type (scenarios 1-4 and 13-16 in Table 1). Absolute uncertainties are too large to be shown, but comparison taking into account correlations revealed statistically significant differences between generic and regionalized damage (see the SI, Section S6.2). Scores for biochar production using Adam retort and earth-mound kilns are presented in the SI, Section S6.1.

Fig. 3. Ranking of biochar systems (all scenarios) in terms of total damage to human health (a) and ecosystems (b) as influenced by switching from generic to regionalized LCA. Values presented in each cell represent to median impact score from 1000 iterations, in DALY/functional unit (a) and species.yr/functional unit (b). A colour scaling system was applied, where colours are determined by values in each cell, where increasing shades of green correspond to biochar systems performing better, respectively. Details of the comparison between systems taking into account uncertainties are presented in SI, Section S6.3. 
system boundaries

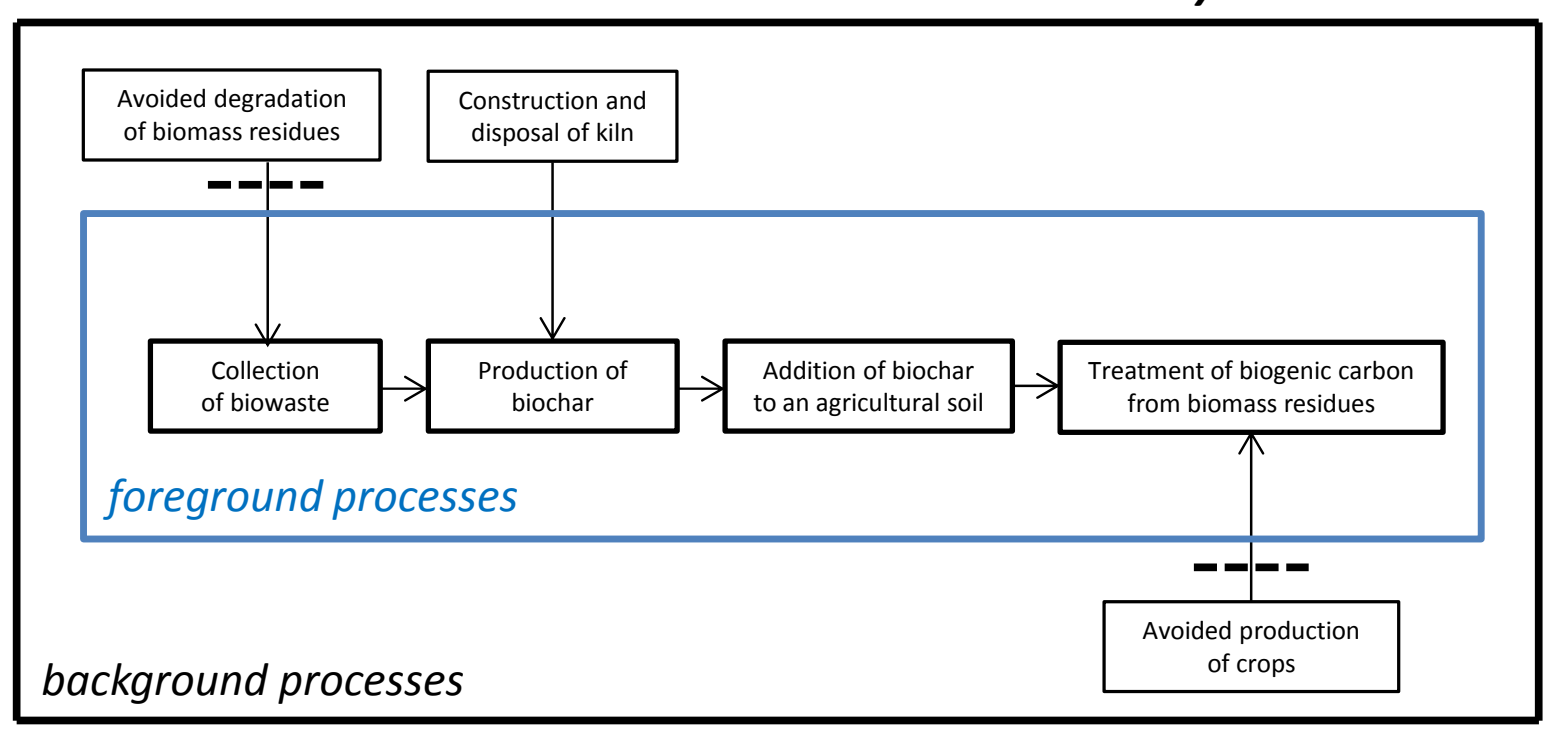

Fig. 1 (in color) 


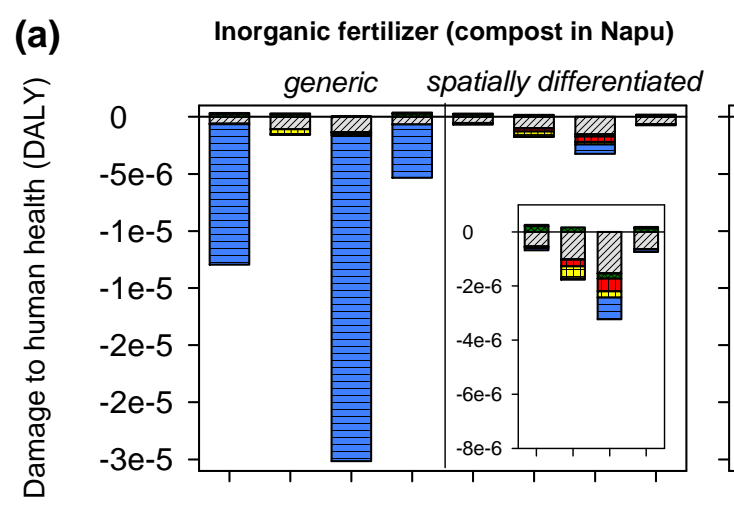

Compost (inorganic fertilizer in Napu)
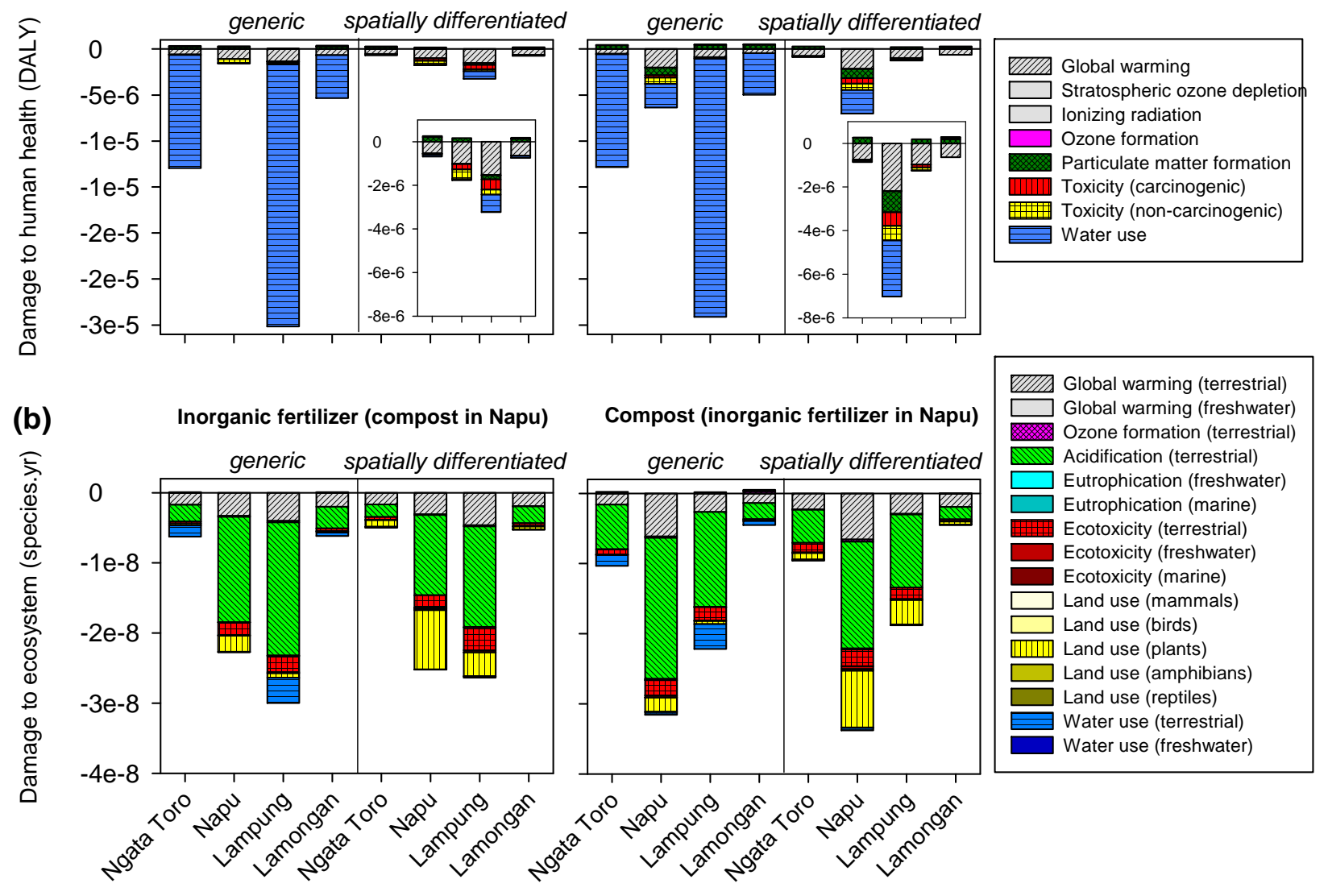

Fig.2 (in color) 
(a)

\begin{tabular}{|c|c|c|c|c|c|c|c|c|c|}
\hline & & & gen & eric & & spati & ally di & ferent & ated \\
\hline 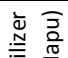 & flame-curtain & $-13 E-05$ & $-13 E-06$ & $-3.0 \mathrm{E}-05$ & -5 . $\mathbb{E}-06$ & $-4.4 \mathrm{E}-07$ & $-18 E-06$ & $-3.2 \mathrm{E}-06$ & $-5.7 E-07$ \\
\hline 芯: & Adam retort & $-13 E-05$ & $-13 \mathrm{E}-06$ & $-3.0 \mathrm{E}-05$ & $-4.8 \mathrm{E}-06$ & $-3.8 \mathrm{E}-07$ & $-18 E-06$ & $-2.8 E-06$ & $-10 \mathrm{E}-07$ \\
\hline ¿ & earth-mound & $-13 E-05$ & $-10 \mathrm{E}-06$ & $-2.8 \mathrm{E}-05$ & $-4.6 \mathrm{E}-06$ & $-18 \mathrm{E}-07$ & $-16 E-06$ & $-3.0 \mathrm{E}-06$ & $-3.6 \mathrm{E}-07$ \\
\hline 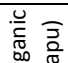 & flame-curtain & $-12 E-05$ & $-6.5 E-06$ & $-2.9 E-05$ & $-4.7 E-06$ & -7.1E-07 & -7.1E-06 & $-1 \mathbb{E}-06$ & $-3.7 E-07$ \\
\hline$\stackrel{\subseteq}{\subseteq}$. & Adam retort & $-13 E-05$ & $-6.3 E-06$ & $-2.9 E-05$ & $-4.9 \mathrm{E}-06$ & $-4.2 \mathrm{E}-07$ & $-7.0 \mathrm{E}-06$ & $-12 E-06$ & $-8.2 E-08$ \\
\hline है & earth-mound & $-12 E-05$ & $-6.4 \mathrm{E}-06$ & $-2.6 \mathrm{E}-05$ & $-2.4 \mathrm{E}-07$ & $-2.4 \mathrm{E}-07$ & -7.1E-06 & $-9.4 E-07$ & $7.5 \mathrm{E}-08$ \\
\hline & & 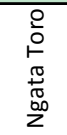 & $\begin{array}{l}\overrightarrow{3} \\
\frac{0}{\pi} \\
z\end{array}$ & 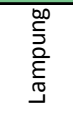 & 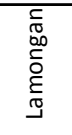 & $\begin{array}{l}0 \\
0 \\
0 \\
0 \\
\pi \\
0 \\
0 \\
Z\end{array}$ & $\begin{array}{l}\vec{a} \\
\frac{0}{\pi} \\
z\end{array}$ & 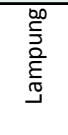 & 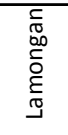 \\
\hline
\end{tabular}

(b)

\begin{tabular}{|c|c|c|c|c|c|c|c|}
\hline \multicolumn{4}{|c|}{ generic } & \multicolumn{4}{|c|}{ spatially differentiated } \\
\hline$-6.5 E-09$ & $-2.4 \mathrm{E}-08$ & $-3 . \mathbb{E}-08$ & $-6.4 \mathrm{E}-09$ & $-5.4 \mathrm{E}-09$ & $-2.7 E-08$ & $-2.7 E-08$ & $-5.6 E-09$ \\
\hline$-5.5 E-09$ & -2.4E-08 & $-3 . \mathbb{E}-08$ & $-4.8 E-09$ & -4.IE-09 & $-2.6 \mathrm{E}-08$ & $-2.4 E-08$ & $-2.3 E-09$ \\
\hline$-4.7 E-09$ & $-2.2 \mathrm{E}-08$ & $-2.9 \mathrm{E}-08$ & $-4.3 \mathrm{E}-09$ & $-4.4 \mathrm{E}-09$ & $-2.6 \mathrm{E}-08$ & $-2.6 \mathrm{E}-08$ & $-4.8 E-09$ \\
\hline$-1 \mathbb{E}-08$ & $-3.4 \mathrm{E}-08$ & $-2.3 \mathrm{E}-08$ & -4.1E-09 & $-10 E-08$ & $-3.6 E-08$ & $-2.0 \mathrm{E}-08$ & $-4.7 E-09$ \\
\hline$-12 \mathrm{E}-08$ & $-3.4 \mathrm{E}-08$ & $-2.5 \mathrm{E}-08$ & $-5.4 \mathrm{E}-09$ & -8.7E-09 & $-3.6 E-08$ & -19E-08 & $-15 E-09$ \\
\hline -9.1E-09 & -3.3E-08 & $-2.2 E-08$ & $-3.3 \mathrm{E}-09$ & $-8.7 E-09$ & $-3.6 E-08$ & $-2.0 \mathrm{E}-08$ & -3.2E-09 \\
\hline $\begin{array}{l}0 \\
\text { 이 } \\
\circ \\
\pi \\
0 \\
0 \\
20 \\
20\end{array}$ & $\begin{array}{l}\vec{a} \\
\frac{0}{\pi} \\
z\end{array}$ & 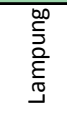 & 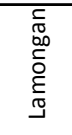 & $\begin{array}{l}0 \\
\text { 이 } \\
\circ \\
\pi \\
0 \\
0 \\
20 \\
0\end{array}$ & $\begin{array}{l}\overrightarrow{2} \\
\frac{2}{\pi} \\
z\end{array}$ & 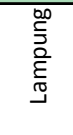 & 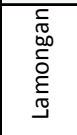 \\
\hline
\end{tabular}

Fig. 3 (in color) 